\title{
Praktek Stimulasi Motorik Kasar Ditinjau dari Pengetahuan Ibu Mengenai Tahap Perkembangan Bayi 0-12 Bulan
}

\author{
Mufida Dian Hardika \\ Akademi Kebidanan Muhammadiyah Madiun Madiun, Jawa Timur, telp. (0351)471000 \\ ${ }^{(*)}$ mufidahardika89@gmail.com
}

ARTICLE INFO A B S T R A C T

Article history:

Received 05 March: 2018

Revised 13 April 2018

Accepted 16 April 2018

Keyword:

Knowledge

Developmental Stage

Stimulation

Psychomotor

(*) corresponding author

DOI:http://dx.doi.org/10.30604/jika.v3i1.79

Psychomotor development is the result of environmental stimulation beyond the individuals associated with the motion and posture. Children who get a good stimulation will grow faster optimally according to age of development. The result of observation in Krajan Posyandu (Maternal \& Child Health Centre), Dolopo village, Madiun region found 60 percent mothers who do not practicing Psychomotoric stimulation yet. It is because the lack of knowledge about the steps of improvement. This study aims to determine the relationship of mother's knowledge about the stages of development with the practice of psychomotor stimulation in infants 0-12 months. This research is a quantitative research using correlational method. Data were collected using questionnaire and check list on 25 respondents. Data were analyzed using Spearman Rank statistic test with significance value $\rho<0,05$. The results of this study showed $\rho$ value of 0.028 ( $\rho$ $<0.05)$. The coefficient correlation between the two variables shows the number 0.439 (Positive) so there is a significant and unidirectional relationship, it shows that there is enough, significant, and the same aim of relation. It is mean that the mothers who have knowledge about developmental stage, psychomotoric stimulation practice skill to infant $0-12$ months will increase. Finally, the researcher gives suggestions. It is supposed there is increasing activity from health officer to mothers by giving information about developmental stage and practice training of psychomotoric stimulation in infant $0-12$ months.

Copyright @ 2018, Jurnal Aisyah: Jurnal Ilmu Kesehatan. All rights reserved.

\section{PENDAHULUAN}

Di Amerika, anak mulai berjalan pada umur 11,4-12,4 bulan, dan anak-anak di Eropa antara 12,4-13,6 bulan. Sedangkan di Indonesia, pada sampel yang diteliti adalah 14,02 bulan. Perbedaan tersebut disebabkan oleh pola pengasuhan anak, lingkungan serta pengetahuan ibu ikut berperan dalam perkembangan seorang anak (Arifin. Y, 2009). Penelitian yang dilakukan oleh Hariweni. T (2010) melalui wawancara terhadap $131 \mathrm{ibu}$ balita yang bekerja dan 
istri karyawan (ibu tidak bekerja) di PT Indofood Sukses Makmur Tanjung Morawa Medan didapatkan hasil bahwa pengetahuan baik tentang stimulasi pada ibu bekerja dan ibu tidak bekerja masingmasing $42(32,1$ persen $)$ dan $64(48,9$ persen). Sikap baik tentang stimulasi pada ibu bekerja dan ibu tidak bekerja masing masing 62 (47,3 persen) dan 18 (13,7 persen). Sedangkan perilaku baik terhadap stimulasi pada ibu bekerja dan ibu tidak bekerja masing-masing 38 (29,0 persen) dan 15 (11,5 persen). Dari penelitian ini dapat disimpulkan bahwa terdapat perbedaan yang bermakna antara ibu bekerja dengan tidak bekerja pada tingkat pengetahuan, sikap dan perilakunya terhadap stimulasi pada pengasuhan anak balitanya.

Masa lima tahun pertama kehidupan merupakan masa yang sangat peka terhadap lingkungan dan masa ini berlangsung sangat pendek serta tidak dapat diulang lagi, maka masa balita disebut sebagai "masa keemasan" (golden period), "jendela kesempatan" (window of opportunity) dan "masa kritis" (critical period) (Depkes RI, 2011). Bahkan ada sarjana yang mengatakan bahwa "The child is the father of the man" sehingga setiap kelainan atau penyimpangan sekecil apapun apabila tidak terdeteksi dan ditangani dengan baik akan mengurangi kualitas sumber daya manusia (Soetjiningsih, 2014).

Pertumbuhan dan perkembangan akan mengakibatkan terjadinya peningkatan kemampuan individu. Tumbuh kembang otak pada usia dini akan meningkatkan ketrampilan anak sehingga anak memiliki kemampuan mengingat sesuatu dan mampu menganalisis suatu masalah. Anak usia 0-1 tahun mulai mengingat dan menganalisis beberapa hal seperti nama, wajah orang, istilah, cahaya, dan warna. Tumbuh kembang tangan dan kaki pada anak akan meningkatkan kemampuan untuk bergerak dan memegang sesuatu benda (Widyani, Retno, 2008).
Menurut Frakenburg dkk mengungkapkan bahwa ada 4 parameter dalam menilai perkembangan balita melalui Denver Developmental Screening Test (DDST) antara lain Personal social (kepribadian/tingkah laku sosial), Fine motor adaptive (gerakan motorik halus), Language (bahasa), Gross motor (perkembangan motorik kasar) (Soetjiningsih, 2014). Motor kasar adalah bagian dari aktivitas motor yg melibatkan ketrampilan otot-otot besar. Gerakangerakan seperti tengkurap, duduk, merangkak, dan mengangkat leher adalah bagian dari aktivitas motor kasar. Gerakan inilah yg pertama terjadi pada tahun pertama usia anak (Sofiany, 2009).

Menstimulasi perkembangan ketrampilan gerak anak sangatlah penting dalam mengasah aspek psikomotorik anak. Dan tentu saja aspek psikomotorik anak sangat berperan dalam aspek kognitif dan afektif anak. Sebab, dengan melatih ketrampilan gerak anak, anak menjadi aktif, pola pikirnya berkembang, dan tubuhnya akan menjadi sehat. Jika sehat, tentu anak itu pun akan menjadi cerdas (Zaviera, 2008). Pemberian stimulasi yang teratur dan terusmenerus akan menciptakan anak yang cerdas, bertumbuh kembang dengan optimal, mandiri, serta memiliki emosi yang stabil, dan mudah beradaptasi (Antara News, 2009).

Menurut Soetjiningsih (2014) stimulasi merupakan hal yang penting dalam tumbuh kembang anak. Anak yang mendapat stimulasi yang terarah dan teratur akan lebih cepat berkembang dibandingkan dengan anak yang kurang/tidak mendapat stimulasi. Stimulasi adalah kegiatan merangsang kemampuan dasar anak umur 0-6 tahun agar anak tumbuh dan berkembang secara optimal. Setiap anak perlu mendapat stimulasi rutin sedini mungkin dan terus menerus pada setiap kesempatan (Depkes RI, 2011).

Berbagai upaya yang dilakukan pemerintah untuk membantu balita mencapai tumbuh 
kembang yang optimal telah dilaksanakan di berbagai tingkat pelayanan diantaranya kegiatan terpadu dan program di Posyandu dan Puskesmas. Meskipun upaya tersebut telah dilaksanakan, namun hasilnya masih belum seperti yang diharapkan (Depkes RI. 2013).

Berdasarkan penelitian Yuniawati (2009), yang dilakukan di Posyandu Sejahtera desa Paron kecamatan Gampengrejo kabupaten Kediri terhadap 18 responden didapatkan hasil bahwa 8 orang (44.4 persen) memiliki pengetahuan cukup, 6 orang (33.3 persen) berpengetahuan baik sedangkan sisanya 4 orang (22.2 persen) berpengetahuan kurang. Hasil praktek stimulasi motorik kasar menunjukkan 14 orang (77.78 persen) melakukan praktek stimulasi motorik kasar dengan cukup baik, 2 orang (11.11 persen) melakukan praktek stimulasi motorik kasar dengan baik dan sisanya 2 orang (11.11 persen) melakukan praktek stimulasi motorik kasar dengan kurang baik. Dengan kesimpulan ada hubungan antara pengetahuan ibu tentang tahap-tahap perkembangan bayi dengan praktek stimulasi motorik kasar pada bayi usia 0-12 bulan, yang ditunjukkan dengan nilai $\rho$ hitung 0,63 .

Target nasional cakupan deteksi dini tumbuh kembang anak balita dan pra sekolah adalah 80 persen. Berdasarkan data Pencapaian Indikator Standar Pelayanan Minimal (SPM) kabupaten Madiun tahun 2017, cakupan deteksi dini tumbuh kembang anak balita dan pra sekolah sebesar 56,14 persen. Sedangkan pencapaian cakupan deteksi dini tumbuh kembang anak balita dan pra sekolah di wilayah kerja Puskesmas Bangunsari sebesar 68 persen. Data hasil survei lapangan di Posyandu Krajan Desa Dolopo Kecamatan Dolopo Kabupaten Madiun, bahwasanya ibu-ibu primipara sejumlah 11 orang belum mengetahui tahap-tahap perkembangan bayi 0-12 bulan, namun diantara mereka ada yang mampu memberikan praktek stimulasi motorik kasar. Pengetahuan tentang stimulasi mereka peroleh dari berbagai media.

Sedangkan ibu-ibu multipara sejumlah 6 orang sudah mengetahui tentang tahaptahap perkembangan pada bayi 0-12 bulan, namun sebagian besar belum melakukan praktek stimulasi motorik kasar dengan berbagai alasan. Alasan dari ibu-ibu atau pengasuh anak yang belum melakukan praktek stimulasi motorik kasar diantaranya kesibukan dengan kegiatan rumah tangga, ibu bekerja, pengetahuan yang kurang tentang praktek stimulasi motorik kasar. Dengan adanya masalah tersebut maka perlu diberikan penyuluhan tentang tahaptahap perkembangan motorik kasar pada bayi dan pengajaran tentang praktek stimulasi motorik kasar terhadap bayi 0-12 bulan bagi orang tua khususnya ibu-ibu atau pengasuh bayi.

Kelambatan perkembangan yang dibiarkan terlalu lama dapat menjadi kelainan atau kecacatan yang sulit diperbaiki di kemudian hari (Depkes RI, 2013). Kurangnya stimulasi dapat menyebabkan penyimpangan tumbuh kembang anak bahkan gangguan yang menetap (Depkes RI, 2011).

Mengingat besarnya dampak yang ditimbulkan dari kelambatan perkembangan serta stimulasi yang diberikan pada bayi usia 0-12 bulan untuk perkembangan berikutnya, maka peneliti tertarik untuk mengambil masalah kurangnya praktek stimulasi motorik kasar pada bayi usia 0-12 bulan di Posyandu Krajan desa Dolopo, untuk judul penelitian "Hubungan Pengetahuan Ibu tentang Tahap-Tahap Perkembangan dengan Praktek Stimulasi Motorik Kasar pada Bayi Usia 0-12 Bulan.

\section{METODE PENELITIAN}

Desain penelitian ini adalah metode korelasional yang bertujuan mengungkapkan hubungan korelatif antar variabel. Variabel independen penelitian ini adalah pengetahuan ibu tentang tahap-tahap 
perkembangan, Instrumen yang digunakan untuk mengukur pengetahuan ibu tentang tahap-tahap perkembangan bayi usia $0-12$ bulan menggunakan kuesioner. Kuesioner ini dibagi menjadi 4 kategori usia, masingmasing untuk 0-3 bulan, 3-6 bulan, 6-9 bulan dan 9-12 bulan. Kuesioner ini dibuat sendiri oleh peneliti, berisi karakteristik responden dan terdiri dari 10 pertanyaan tertutup.

Variabel dependen adalah Praktek stimulasi motorik kasar pada bayi usia 0-12 bulan, Instrumen yang digunakan untuk mengukur praktek stimulasi motorik kasar menggunakan checklist, Check list dibuat berdasarkan pedoman pelaksanaan stimulasi, deteksi dan intervensi dini tumbuh kembang anak ditingkat pelayanan kesehatan dasar yang dikeluarkan oleh Depkes RI. Check list ini dibagi menjadi 4 kategori usia, masing-masing untuk 0-3 bulan terdiri dari 9 item penilaian, 3-6 bulan, 6-9 bulan dan 9-12 bulan terdiri dari 15 item penilaian.

Teknik pengambilan sampel menggunakan sampling jenuh, dimana semua anggota populasi dijadikan sampel. Tempat penelitian di Posyandu Krajan, Desa Dolopo, Kecamatan Dolopo, Kabupaten Madiun mulai bulan Januari 2018 hingga Februari 2018. Populasi dalam penelitian ini adalah semua ibu (primipara dan multipara) yang mempunyai bayi usia 0-12 bulan, sejumlah 30 ibu. Pengujian statistik menggunakan uji Spearman Rank.

\section{HASIL DAN PEMBAHASAN}

Gambar 1. Karakteristik Responden Berdasarkan Umur

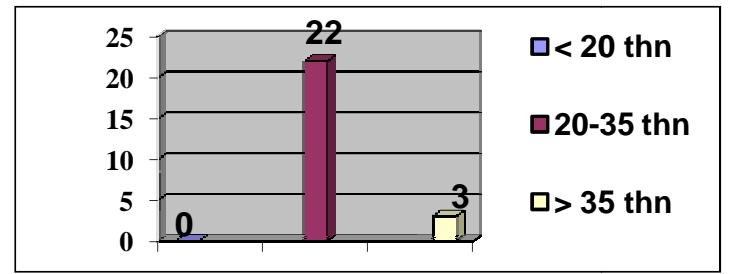

Berdasarkan gambar 1, tidak ada responden yang berusia kurang dari 20 tahun (0 persen), hampir seluruh responden berusia 20-35 tahun berjumlah 22 orang ( 88 persen) dan hanya sebagian kecil responden yang berusia lebih dari 35 tahun sebanyak 3 orang (12 persen).

\section{Gambar 2. Karakteristik Responden Berdasarkan Tingkat Pendidikan}

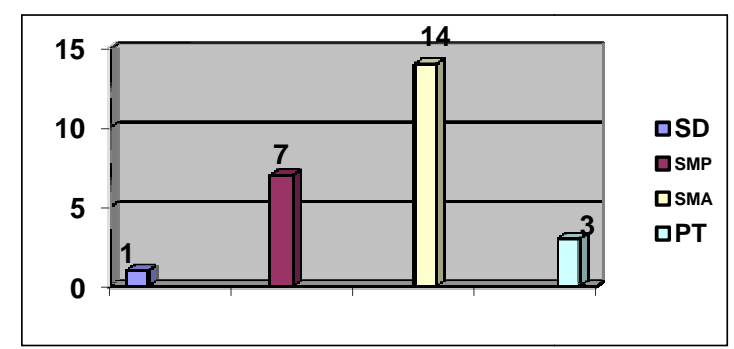

Berdasarkan gambar 2, hanya sebagian kecil responden yang berpendidikan SD sebanyak 1 orang (4 persen), Perguruan Tinggi sebanyak 3 orang (12 persen), hampir setengahnya berpendidikan SMP yaitu sebanyak 7 orang (28 persen) dan sebagian besar berpendidikan SMA yaitu sebanyak 14 orang (56 persen).

Gambar 3. Karakteristik Responden Berdasarkan Pekerjaan



Berdasarkan gambar 3, Karakteristik responden berdasarkan pekerjaan yaitu hampir seluruh responden tidak bekerja yaitu sebanyak 19 orang (76 persen) serta sebagian kecil sebagai PNS 2 orang (8 persen) dan swasta 4 orang (16 persen).

\section{Gambar 4. Karakteristik Responden} Berdasarkan Jumlah Anak.

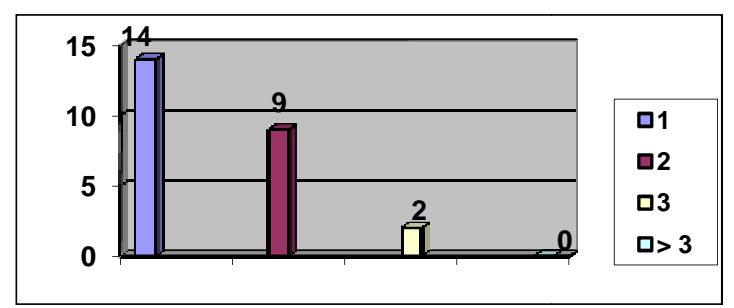


Berdasarkan Gambar 4, sebagian besar mempunyai 1 anak sebanyak 14 orang (56 persen), hampir setengahnya mempunyai 2 anak sebanyak 9 orang (36 persen), sebagian kecil mempunyai 3 anak sebanyak 2 orang ( 8 persen) dan tidak satupun responden yang mempunyai anak lebih dari 3 (0 persen).

\section{Gambar 5. Karakteristik Responden Berdasarkan Usia Anak}

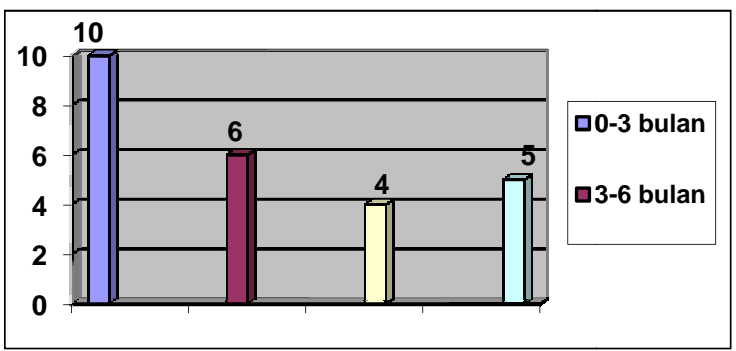

Berdasarkan gambar 5, hampir setengah responden yang memiliki anak usia 0-3 bulan sebanyak 10 orang (40 persen), memiliki anak usia 3-6 bulan sebanyak 6 orang (24 persen), 6-9 bulan sebanyak 4 orang (16 persen) serta 9-12 bulan sebanyak 5 orang (20 persen).

\section{Gambar 6. Pengetahuan Ibu tentang Tahap- Tahap Perkembangan.}

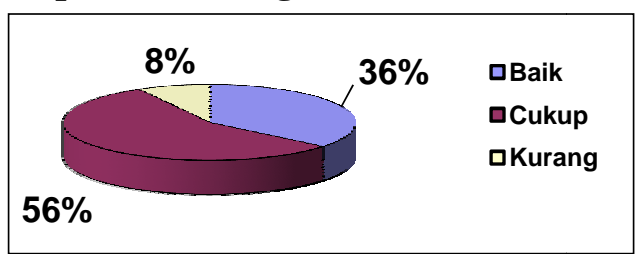

Berdasarkan gambar 6, hampir setengahnya berpengetahuan baik sebanyak 9 orang (36 persen), sebagian besar berpengetahuan cukup sebanyak 14 orang (56 persen) dan sebagian kecil berpengetahuan kurang sebanyak 2 orang (8 persen).

Dari data tersebut dapat diketahui bahwa sebagian besar pengetahuan ibu cukup, hal ini bisa disebabkan oleh karena mereka menganggap informasi tentang tahap-tahap perkembangan bayi terutama di usia 0-12 bulan tidak begitu penting. Mereka lebih mementingkan kebutuhan pemenuhan gizi dari anaknya, padahal kebutuhan untuk perkembangan bayi tidak hanya tertuju pada pemenuhan gizi saja tetapi masih banyak faktor -faktor lain yang mendukung.

Selain itu juga, kemungkinan disebabkan sebagian besar ibu kurang pengalaman dalam merawat dan mengasuh anak karena ibu mempunyai satu anak yaitu sebanyak 14 orang (56 persen), serta usia ibu sebagian besar adalah 20-35 tahun yaitu sebanyak 22 orang (88 persen). Hal ini sesuai dengan yang ditulis oleh (Putro, 2009) bahwa semakin cukup umur, tingkat kematangan dan kekuatan seseorang akan lebih matang dalam berfikir dan logis.

Pendidikan juga sangat berperan dalam menambah pengetahuan seseorang. Dalam penelitian ini sebagian besar ibu berpendidikan menengah (SMA) yaitu sebanyak 14 orang (56 persen). Hal ini sesuai dengan pendapat Nursalam (2013), mengatakan bahwa pendidikan diperlukan untuk mendapatkan informasi. Makin tinggi tingkat pendidikan seseorang, maka makin mudah menerima informasi sehingga makin banyak pengetahuan yang dimiliki dan semakin mudah orang tersebut menerima informasi, sehingga seseorang lebih mudah menerima terhadap nilai-nilai yang baru dikembangkan.

Gambar 7. Praktek Stimulasi Motorik Kasar

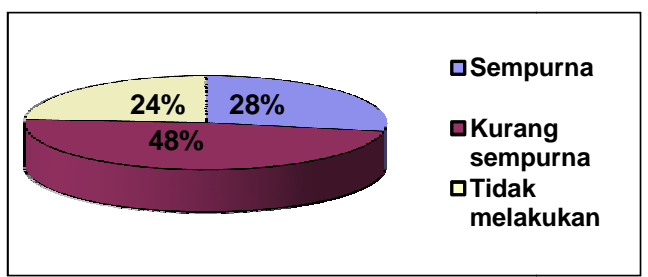

Berdasarkan gambar 7, hampir setengah dari responden melakukan praktek stimulasi motorik kasar dengan kurang sempurna sebanyak 12 orang (48 persen), hampir setengahnya lagi melakukan dengan sempurna sebanyak 7 orang (28 persen) dan hanya sebagian kecil saja yang tidak 
melakukan praktek stimulasi motorik kasar yaitu sebanyak 6 orang ( 24 persen).

Hal ini kemungkinan disebabkan sebagian besar responden mempunyai satu anak yaitu sebanyak 14 orang (56 persen), sehingga ibu sulit untuk melakukan praktek stimulasi motorik kasar secara sempurna. Hal ini sesuai dengan pendapat Latipun (2009) untuk dapat mempunyai tanggapan dan penghayatan seseorang harus mempunyai pengalaman yang berkaitan dengan obyek psikologis.

Selain itu pendidikan ibu yang sebagian besar berpendidikan menengah (SMA) yaitu sebanyak 14 orang (56 persen) juga berperan dalam melakukan praktek stimulasi ini. Menurut Soetjiningsih (2014), pendidikan orang tua merupakan salah satu faktor penting dalam tumbuh kembang anak karena pendidikan yang baik maka orang tua menerima segala informasi dari luar yaitu tentang cara pengasuhan anak yang baik terutama dalam melakukan dan memberi stimulasi pada anak.
Kegiatan para orang tua atau pengasuh yang telah dilakukan turun temurun seperti membelikan mainan kerincingan, boneka, bola dan lain-lain, mengajak anak bermain ci luk ba, serta membantu anak pada saat belajar berjalan merupakan salah satu cara memberikan stimulasi motorik kasar terhadap bayi usia 0-12 bulan.

Namun mereka tidak tahu bila kegiatankegiatan tersebut bermanfaat, sehingga kegiatan tersebut dilakukan begitu saja tanpa ada peningkatan pengetahuan caracara stimulasi yang lain. Hal ini sesuai dengan pendapat Latipun (2009) bahwa ketidaksanggupan keluarga mengambil keputusan dalam melakukan tindakan yang tepat karena tidak memahami sifat, berat dan luasnya masalah serta tidak sanggup menyelesaikan masalah karena kurangnya pengetahuan.

Hal ini berkaitan pula bila timbul keterlambatan perkembangan, keluarga tidak mampu memberikan stimulasi karena kurangnya pengetahuan.

Tabel 1. Tabulasi Silang Hubungan Pengetahuan Ibu Tentang Tahap-Tahap Perkembangan dengan Praktek Stimulasi Motorik Kasar Pada Bayi Usia 0 - 12 Bulan.

\begin{tabular}{|c|c|c|c|c|c|c|c|c|c|}
\hline & & \multicolumn{6}{|c|}{ Praktek } & \multicolumn{2}{|c|}{ Total } \\
\hline & & \multicolumn{2}{|c|}{$\begin{array}{c}\text { Tidak } \\
\text { Melakukan }\end{array}$} & \multicolumn{2}{|c|}{$\begin{array}{c}\text { Kurang } \\
\text { Sempurna }\end{array}$} & \multicolumn{2}{|c|}{ Sempurna } & \multirow[b]{2}{*}{$\mathrm{Jm} 1$} & \multirow[b]{2}{*}{$\%$} \\
\hline & & $\mathrm{Jm} 1$ & $\%$ & $\mathrm{Jml}$ & $\%$ & $\mathrm{Iml}$ & $\%$ & & \\
\hline \multirow{3}{*}{$\begin{array}{l}\text { Pengeta } \\
\text { huan }\end{array}$} & Kurang & 1 & $4 \%$ & 1 & $4 \%$ & 0 & $0 \%$ & 2 & $8 \%$ \\
\hline & Cukup & 5 & $20 \%$ & 6 & $24 \%$ & 3 & $12 \%$ & 14 & $56 \%$ \\
\hline & Baik & 0 & $0 \%$ & 5 & $20 \%$ & 4 & $16 \%$ & 9 & $36 \%$ \\
\hline \multicolumn{2}{|c|}{ Total } & 6 & $24 \%$ & 12 & $48 \%$ & 7 & $28 \%$ & 25 & $100 \%$ \\
\hline
\end{tabular}

Berdasarkan tabel 1 diketahui hubungan pengetahuan dengan praktek stimulasi motorik kasar pada bayi usia 0-12 bulan adalah ibu yang berpengetahuan kurang serta tidak melakukan praktek stimulasi motorik kasar sebanyak 1 orang (4 persen), melakukan dengan kurang sempurna 1 orang (4 persen) dan tidak ada yang melakukan dengan sempurna ( 0 persen).

Ibu yang berpengetahuan cukup serta tidak melakukan praktek stimulasi motorik kasar sebanyak 5 orang (20 persen), melakukan dengan kurang sempurna 6 orang (24 persen) dan melakukan dengan sempurna 3 orang (12 persen). Sedangkan ibu yang 
berpengetahuan baik serta tidak melakukan praktek stimulasi motorik kasar sebanyak 0 orang (0 persen), melakukan dengan kurang sempurna 5 orang $(20$ persen $)$ dan melakukan dengan sempurna 4 orang (16 persen).

Tabel 2. Hasil penghitungan Spearman Rank

\begin{tabular}{|c|l|l|r|r|}
\hline \multicolumn{2}{|c|}{} & Pengetahuan & \multicolumn{1}{c|}{ Praktek } \\
\hline $\begin{array}{c}\text { Spearman's } \\
\text { rho }\end{array}$ & Pengetahuan & Correlation & 1.000 & $.439^{*}$ \\
& & Coefficient & & \\
& & Sig. (2-tailed) & & .028 \\
& N & 25 & 25 \\
\hline & Praktek & Correlation & $.439^{*}$ & 1.000 \\
& & Coefficient & & \\
& & Sig. (2-tailed) & .028 & \\
& & N & 25 & 25 \\
\hline
\end{tabular}

Hubungan Pengetahuan Ibu tentang Tahap-Tahap Perkembangan dengan Praktek Stimulasi Motorik Kasar Pada Bayi Usia 0-12 Bulan

Berdasarkan Tabel 2, hasil penghitungan uji hipotesis Spearman Rank dengan bantuan SPSS 17 for windows yang telah dilakukan menunjukkan nilai $\rho 0,028<0,05$ artinya ada hubungan antara pengetahuan ibu tentang tahap-tahap perkembangan dengan praktek stimulasi motorik kasar pada bayi usia $0-12$ bulan.

Korelasi antara variabel "pengetahuan tentang tahap-tahap perkembangan" dengan "praktek stimulasi motorik kasar" menunjukkan angka sebesar 0,439 yang artinya terdapat hubungan yang cukup dan searah. Ini berarti, makin tinggi pengetahuan ibu tentang tahap-tahap perkembangan maka makin meningkat pula praktek stimulasi motorik kasar pada bayi usia $0-12$ bulan.

Sedangkan signifikansi hubungan variabel "pengetahuan tentang tahap-tahap perkembangan" dengan "praktek stimulasi motorik kasar" menunjukkan nilai $\rho=$ 0,028 artinya hubungan kedua variabel tersebut signifikan.

Jadi orang tua yang memiliki pemahaman yang baik mengenai tahap-tahap perkembangan, mereka akan memberikan stimulasi atau rangsangan yang tepat dan sesuai dengan tahap perkembangannya juga. Biasanya mereka menciptakan suasana yang hangat, penuh kasih sayang dan penuh cinta, serta penuh dengan stimulasi-stimulasi yang positif.

Menurut penelitian Rogers (1974) yang dikutip Notoatmodjo (2015) ternyata pengetahuan atau kognitif merupakan domain yang sangat penting dalam membentuk tindakan seseorang karena itu perilaku yang didasari oleh pengetahuan akan lebih langgeng daripada perilaku yang tidak didasari oleh pengetahuan.

Peranan orang tua merupakan salah satu faktor yang penting dalam perkembangan bayi. Dimana orang tua yang tanggap dengan pertumbuhan dan perkembangan anak akan berpengaruh besar terhadap tumbuh kembangnya.

Maka kesimpulan dari penelitian antara variabel pengetahuan tentang tahap-tahap perkembangan dengan praktek stimulasi motorik kasar pada bayi usia 0-12 bulan ini ialah ada hubungan yang cukup, signifikan dan searah. Hal ini sesuai dengan penelitian Yuniawati (2009), di Posyandu Sejahtera desa Paron kecamatan Gampengrejo kabupaten Kediri yang juga berkesimpulan ada hubungan antara pengetahuan ibu tentang tahap-tahap perkembangan bayi dengan praktek stimulasi motorik kasar pada bayi usia 0-12 bulan, yang 
ditunjukkan dengan nilai $\rho$ hitung 0,63 ( $\rho$ tabel $=0,4750)$.

\section{KESIMPULAN DAN SARAN}

Berdasarkan penelitian yang dilakukan dapat disimpulkan bahwa, Pengetahuan ibu tentang tahap-tahap perkembangan pada bayi usia $0-12$ bulan sebagian besar cukup, Dalam melakukan praktek stimulasi motorik kasar pada bayi usia 0-12 bulan hampir setengah dari responden berpengetahuan kurang. Serta ada hubungan antara pengetahuan ibu tentang tahap-tahap perkembangan dengan praktek stimulasi motorik kasar pada bayi usia 0-12 bulan.

Beberapa saran yang dapat diberikan terkait penelitian ini adalah, Bagi Profesi Kebidanan diharapkan bagi bidan untuk memberikan penyuluhan tentang tahaptahap perkembangan bayi dan adanya peningkatan penyuluhan dan praktek stimulasi motorik kasar. Bagi peneliti selanjutnya diharapkan penelitian ini dikembangkan pada populasi yang lebih besar, dan dapat mengungkap lebih banyak permasalahan dan memberikan pemecahan masalah yang berarti dan bermanfaat bagi banyak pihak.

Diharapkan pula penelitian ini bisa menjadi bahan masukan bagi institusi pendidikan untuk penelitian lebih lanjut tentang praktek stimulasi motorik kasar. Saran bagi responden, hendaknya selalu meningkatkan pengetahuan utamanya tentang tahap-tahap perkembangan anak dan senantiasa memberikan stimulasi yang terarah dan teratur. 


\section{DAFTAR PUSTAKA}

Antara News. (2009). Stimulasi Terus Menerus Pada Balita Dapat Ciptakan Anak Cerdas, (Online), (http://www.antara.co.id/peristiwa), diakses 23 Desember 2017.

Arifin, Y. (2009). Hubungan Tingkat Pengetahuan Ibu Tentang Stimulasi Dengan Perkembangan Motorik Kasar Anak Usia 3-5 Tahun Di Desa Mekar Sari Kecamatan Delitua Kabupaten Deli Serdang, (Online), (http://httpyasirblogspotcom.blogsp ot.com/2009/02/hubungan-tingkatpengetahuan-ibu.html ), diakses 17 Januari 2018.

Depkes RI. (2011). Pedoman Pembinaan Perkembangan Anak Di Keluarga. Jakarta: DepkesRI

. (2011). Pedoman Deteksi Dini Tumbuh Kembang Balita. Jakarta: DepkesRI

. (2013). Petunjuk Pelaksana Deteksi Tumbuh Kembang Balita Bayi pada Petugas Puskesmas. Jakarta: DepkesRI

Hariweni, T. (2010). Pengetahuan, Sikap Dan Perilaku Ibu Bekerja Dan Tidak Bekerja Tentang Stimulasi Pada Pengasuhan Anak Balita, (Online), (http://library.usu.ac.id/index.php/co mponent/journals/index.php?option $=\mathrm{com} \_$journals $\& \mathrm{sf}=\mathrm{keyword} \& \mathrm{keyw}$ ord=perilaku\%20ibu\%20bekerja\&ta sk=search09), diakses 12 Desember 2017.

Latipun, (2009). Psikologi Konseling. Malang: UMM Press

Muhammad. (2009). Sepuluh Kesalahan dalam Mendidik Anak. (Online), tanggal akses 23 Januari 2018
Notoatmodjo, S. (2015). Metodologi Penelitian Kesehatan. Jakarta: Rineka Cipta.

Nursalam. (2013). Konsep dan Penerapan Metodologi Ilmu Keperawatan. Jakarta: Salemba Medika..

Putro. (2009). Konsep Kesehatan dan Teknologi, (Online), (http://cahyonoputra.blogspot.com/2 009/02/konsep-pengetahuan.html,), diakses 24 Desember 2017.

Sofiany, R. (2009). Mengoptimalkan Perkembangan Motor Bayi 0-12 Bulan, (Online), (http://www.balitaanda.com/), diakses 16 Januari 2018.

Soetjiningsih. (2014). Tumbuh Kembang Anak. Jakarta: EGC.

Widyani, Retno. (2007). Panduan Perkembangan Anak 0-1 Tahun. Jakarta: Puspa Swara.

Yuniawati, R.D. (2009). Hubungan Pengetahuan Ibu Tentang Tahaptahap Perkembangan dengan Praktek Stimulasi Motorik Kasar Pada Bayi Usia 0-12 Bulan di Posyandu Sejahtera Desa Paron Kecamatan Gampengrejo Kabupaten Kediri. Karya Tulis Ilmiah tidak diterbitkan. Kediri: Program Studi Kebidanan. Jurusan Kebidanan. Poltekkes Depkes Malang.

Zaviera, F. (2008). Mengenal dan Memahami Tumbuh Kembang Anak. Yogyakarta: Kata Hati. 
J urnal Aisyah: J urnal Ilmu Kesehatan, 3(1), J uni 2018, - 38

Mufida Dian Hardika 